Int.J. Hum. Soc. Dev. Res.

ISSN (P):2521-1439; ISSN (E):2523-4331

Volume 1, № 1, 2017. 55-67

DOI:10.30546/2523-4331.2017.1.1.55

\title{
Era of Economic Recession in Nigeria: Impacts and Survival Strategies for Managing Private Universities
}

\author{
MURAINA, Monsuru Babatunde \\ Al-Hikmah University, Ilorin, Nigeria
}

(C) The Author(s) 2017

\begin{abstract}
The present economic recession cum financial crisis in Nigeria have undoubtedly sent Tsunami ripples and wave shocks across the various sectors of the country, including educational sector. University education which is expected to provide the manpower requirement of the country in adequate quantity and quality are seriously being affected. The Nigerian universities are characterized by incessant strike action as a result of non-payment of staff salaries and allowances, presence of corruption in the system etc. The private universities suffer much because they are not being grantaided by the government. The enrolment rate in these private universities is extremely low, making it difficult for them to meet up with their financial obligations, the dividends of which led to retrenchment and downsizing in these universities. Some of the private universities in Nigeria are seriously affected due to this economic malady in the country. This is because tuition fees are the major sources of revenue for them. Previous studies have examined the history of private universities in Nigeria, the role of university education in national development as well as prospects and problems of university education in Nigeria. The present study therefore takes a step further to examining the impacts and survival strategies of managing private universities in Nigeria during this era of chronic economic recession. To do this, tremendous efforts were made to examine the concept of economic recession and its history, the concept and goals of university education, the history of private participation in university education; the impacts of the era of economic recession on managing private universities in Nigeria and survival strategies for managing private universities during the era of economic recession. It was therefore recommended that the private universities should diversify into revenue generating businesses so as to utilize the dividends from such to supplement the tuition fees.

C2017.All rights reserved
\end{abstract}

\section{ARTICLE HISTORY}

Received: 17/12/2016

Accepted: 16/03/2017

Published online: 26/04/2017

\section{KEYWORDS}

Economic Recession, financial crisis, Nigerian Univeristies, private universities, university education.

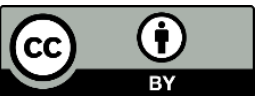

www.ijhsdr.com 


\section{Introduction}

Economic crises or recession involves the growing economic, political, technological and socio-cultural linkages which connect individuals, governments at all level and societies at large and its negative impacts on people. Undoubtedly, Nigerian economy has over the years being facing and struggling with the rippling effects of the economic recession resulting into total breakdown and decline in the country's economic vigor. This is evident in the high rate of unemployment, crashes of Nigerian currency, galloping inflation as well as declining business and unpaid salaries and allowances of workers. Therefore, every sector of the country's economy has had its fair share of the troubles and menace of economic recession. The education sector (University education inclusive) which is expected to train the manpower requirements of the country has shared highest part of the effect of economic recession. The private universities which are majorly financed by the private individuals are finding it difficult to survive in this era of economic recession or malady. In fact, the public (State and Federal Universities) are really suffering from dearth of infrastructures, inadequate funds and others. This contributes to incessant strikes of universities staff, unpaid salaries of universities staff, prolonged academic calendar and a host of others. Many private universities therefore are now finding it difficult too to pay their workers regularly, there are cases of retrenchment and downsizing in some private universities, thereby, improving the unemployment saga in the country. This is because, the private universities in Nigeria are not being grant-aided by the government and the possibility of meeting up with their financial obligations at this tedious era of economic recession is becoming difficult and unrealistic for these private universities in the country.

Therefore, the thrust of this paper examines the impacts of economic recession in Nigeria on the management of private universities in the country and also the survival tips for the management of private universities in Nigeria during the economic recession.

\section{Economic Recession: Concept and History}

Economic recession refers to economic slowdown, characterized by low output, illiquidity, poor exchange rate and mass unemployment. It is also characterized by abnormal rise in unemployment rate, fall in the availability of credit, volatile currency value fluctuations, devaluations, decline investment and bank failure. A recession has various attributes which can occur parripasu or simultaneously and it may include decline in the component measures of economic activity (GDP) such as consumption, investment, government spending and Net 
export. According to National Bureau of Economic Research (NBER) (2005), recession is a significant decline in economic activity spread across the economy, lasting more than a few months, normally visible in a real Gross Domestic Product (GDP), real income, employment, industrial production and wholesale-retail sales.

Historically, the first recorded economic crisis occurred in the Third Century when Roman Empire encountered collapsed as a result of pressure brought by invasion, plague, civil war and economic depression (Babalola, 2016). Records showed that this made the Roman Empire to divide into three comprising Gallic Empire, Palmyrene Empire and an independent Roman Empire.

Furthermore, economic crisis were recorded in the 4th, 17th, 18th, 19th, 20th and late 21st Centuries. Accordingly, the most powerful and serious economic crisis was that of 1930 which greatly affected a good number of countries, including the United States of America (USA). This crisis started in the United States as a result of the fall in stock prices on 4th September, 1929 and culminated in a global World stock market crash on October 29th, 1929.

In 2014, Russia also started to experience a financial crisis brought as a result of International Sanction imposed on the country due to its annexation of Crimea and the decline in the price of oil.

\section{The Concept and Goals of University Education in Nigeria}

Traditionally, a university is an academic community of students, teaching staff and non-teaching staff. It can also be regarded as an organization empowered by law to manage its activities and it is characterized by a long standing tradition of academic freedom and operational autonomy. According to Eze (2000), university is a separate community of masters and students isolated from the immediate environment. To Livingstone (1974), as referenced by Babalola (2015), a university is a set of buildings, an idea, a concept or even a society. Corroborating this, Sanda (1992) saw university as an organization being essentially a social grouping of human beings whose activities are co-ordinated and directed towards the achievement of specific goals. It is a community, a bureaucracy, a monastery, an institution, a political entity or even a business outfit (Babalola, 2015). It is an institution of higher education, learning and research which grants academic and professional degrees in a variety of disciplines or professions. It provides courses of instruction and other facilities for the acquisition of knowledge in all fields, to 
encourage the advancement of learning, culture and character, encourage and promote scholarship and to conduct research in all fields of learning and human endeavour and ultimately to relate all its activities to the social, cultural and economic needs of mankind (Omoregie, 1997).

Therefore, university education is regarded as a specialized and higher form of education. Specifically, Section 5, Sub-Section 86 of the Federal Republic of Nigeria National Policy on Education (2013) states the goals of university education to include, to:

a.Intensify and diversify its programmes for the development of high level manpower within the context of the needs of the nation;

b.Make professional course contents reflect our national requirements;

c.Make all students part of a general programme of all round improvement in university education to offer general study courses such as history of ideas, philosophy of knowledge, nationalism and Information Technology (IT); and

d.Make entrepreneurial skills acquisition a requirement for all Nigerian universities.

\section{The History of Private Sector Participation in University Education in Nigeria}

Private sector participation in university education refers to the process of deregulation of university education. According to Ajayi and Ekundayo (2008), deregulation of university education implies the process of breaking the government's monopolistic power or influence on the provision and management of university education by way of giving free hand to private participation in the provision and management of university education in the country.

Historically speaking and according to Oloyede and Adekola (2010), private universities are recent developments in Nigeria compared to the public counterparts. However, these developments evolved during two historic phases. The first being during the Second Republic under President ShehuShagari's administration (1979-1983) and the second phase being during the Fourth Republic under President OlusegunAremuObasanjo (1999-2007). Therefore, the first private university in Nigeria was Tandem University, Owerri, founded by Basil NnanaUkaegbu in 1980 (Adeogun, etal., 2009 and Gabriel, eta., 2006). Though, the establishment of the university witnessed judicial contest, notwithstanding, the 
victory of the founder at the Supreme Court enhanced the private individuals and organizations to establish private universities in the country. During this time, a total of 26 private universities were established in the Southern part of the country (Osagie, 2009). In December, 1983 under General MuhammaduBuhari, Decree No 19 of June 1984 was enacted, abolishing and prohibiting the establishment of private universities in the country (Obasi, 2007).

Nevertheless, the establishment of private universities in Nigeria was redeemed with the inauguration of the Commission on the Review of higher education by the Head of State, General Ibrahim Babangida in 1991. The recommendation of the Commission (Longe Commission) therefore made the government to reverse the former Decree on the establishment of private universities. Thus, this allowed private individuals to establish and run private universities in the country on the ground that they meet the standard guidelines and obtain government's approval. Arising from this, the National Universities Commission (NUC) established in May, 1993, the Standing Committee on the establishment of private universities (SCOPU), which was saddled with the responsibility of evaluationg the process of establishing private universities in the country (Okojie, 2008).

Meanwhile, with the emergence of democracy in 1999, under President OlusegunAremuObasanjo, private universities rose drastically. Hence, the first set of private universities which gained approval in 1999 were: Igbinedon university, Okada; Babcock University, Ilisan-Remo and Madona university, Okija (Omuta, 2010), with Igbinedon university, Okada being the first licensed private university in Nigeria (Owoye, 2012). Presently therefore, the number of private universities in the country has increased fantastically.

The table below shows the lists of private universities in Nigeria, location and year of establishment between 1999 and 2017: 
Table 1: List of Private Universities in Nigeria as at 2017

Source: National Universities Commission (NUC) - Google Search, 13/2/2017

\begin{tabular}{|c|c|c|}
\hline S/N Name of University & Location & $\begin{array}{r}\text { Year } \\
\text { Established }\end{array}$ \\
\hline 1. Fountain University & $\begin{array}{l}\text { Oshogbo, Osun } \\
\text { State }\end{array}$ & 2007 \\
\hline 2. Bingham University & $\begin{array}{r}\text { New Karu, } \\
\text { Nassarawa State }\end{array}$ & 2005 \\
\hline $\begin{array}{l}\text { 3. Wukari Jubilee University } \\
\text { (Kwarafa University) }\end{array}$ & $\begin{array}{l}\text { Wukari, Taraba } \\
\text { State }\end{array}$ & 2005 \\
\hline $\begin{array}{l}\text { 4. American University of } \\
\text { Nigeria (ABTI) }\end{array}$ & $\begin{array}{l}\text { Yola, Adamawa } \\
\text { State }\end{array}$ & 2003 \\
\hline 5. Pan Atlantic university & Lagos State & 2002 \\
\hline 6. $\quad$ Caritas University & $\begin{array}{l}\text { Amorji-Nke, } \\
\text { Enugu State }\end{array}$ & 2005 \\
\hline 7. Western Delta University & $\begin{array}{l}\text { Oghara, Delta } \\
\text { State }\end{array}$ & 2007 \\
\hline 8. Wellspring University & $\begin{array}{l}\text { Evbuobosa, Edo } \\
\text { State }\end{array}$ & 2009 \\
\hline 9. University of Mkar & Mkar, Benue State & 2005 \\
\hline 10. Salem University & Lokoja, Kogi State & 2007 \\
\hline 11. Oduduwa University & $\begin{array}{l}\text { Ipetumudu, Osun } \\
\text { State }\end{array}$ & 2009 \\
\hline 12. Obong University & $\begin{array}{l}\text { Obong Ntak, Akwa } \\
\text { Ibom State }\end{array}$ & 2007 \\
\hline 13. Novena University & $\begin{array}{l}\text { Ogume, Delta } \\
\text { State }\end{array}$ & 2005 \\
\hline 14. Renaissance University & Enugu State & 2005 \\
\hline $\begin{array}{l}\text { 15. Nigerian Turkish Nile } \\
\text { university }\end{array}$ & Abuja & 2009 \\
\hline 16. Madona University & Okija, Elele & 1999 \\
\hline 17. Lead City University & Ibadan, Oyo State & 2005 \\
\hline 18. Baze University & Abuja & 2011 \\
\hline 19. Landmark University & $\begin{array}{l}\text { Omu Aran, Kwara } \\
\text { State }\end{array}$ & 2011 \\
\hline 20. Igbinedion University & Okada, Edo State & 1999 \\
\hline 21. Redeemers University & Ede, Osun State & 2005 \\
\hline $\begin{array}{l}\text { 22. Joseph Ayo Babalola } \\
\text { University }\end{array}$ & $\begin{array}{l}\text { Ikija, Ilesha, Osun } \\
\text { State }\end{array}$ & 2006 \\
\hline 23. Crawford University & Igbesa, Ogun State & 2005 \\
\hline 24. Covenant University & Ota, Ogun State & 2002 \\
\hline 25. Caleb University & Imota, Lagos State & 2007 \\
\hline 26. Afe Babalola University & $\begin{array}{l}\text { Ado Ekiti, Ekiti } \\
\text { State }\end{array}$ & 2009 \\
\hline 27. Bowen University & Iwo, Osun State & 2001 \\
\hline
\end{tabular}




\begin{tabular}{|c|c|c|}
\hline $\begin{array}{l}\text { 28. Benson Idahosa } \\
\text { University }\end{array}$ & $\begin{array}{l}\text { Benin City, Edo } \\
\text { State }\end{array}$ & 2002 \\
\hline $\begin{array}{l}\text { 29. Bells University of } \\
\text { Technology }\end{array}$ & Ota, Ogun State & 2004 \\
\hline 30. Babcock University & Ilisan, Ogun State & 1999 \\
\hline $\begin{array}{l}\text { 31. Ajayi Crowther } \\
\text { University }\end{array}$ & Oyo, Oyo State & 2005 \\
\hline $\begin{array}{l}\text { 32. The African University of } \\
\text { science \&Technology }\end{array}$ & Abuja & 2007 \\
\hline 33. Achievers University & Owo, Ondo State & 2007 \\
\hline 34. McPherson University & $\begin{array}{l}\text { Seriki Sotayo, } \\
\text { Ogun State }\end{array}$ & 2012 \\
\hline 35. South Western University & $\begin{array}{l}\text { Okunowa, Ogun } \\
\text { State }\end{array}$ & 2012 \\
\hline 36. Evangel University & $\begin{array}{l}\text { Akaeze, Ebonyi } \\
\text { State }\end{array}$ & 2012 \\
\hline $\begin{array}{l}\text { 37. Samuel Adegboyega } \\
\text { University }\end{array}$ & Ogwa, Edo State & 2011 \\
\hline 38. Adeleke University & Ede, Osun State & 2011 \\
\hline 39. Elizade University & $\begin{array}{l}\text { Ilara Mokin, Ondo } \\
\text { Sate }\end{array}$ & 2012 \\
\hline 40. $\mathrm{Al}$ - Hikman University & Ilorin, Kwara State & 2005 \\
\hline 41. CETEP City University & Lagos & 2005 \\
\hline $\begin{array}{l}\text { 42. Godfrey Okoye } \\
\text { University }\end{array}$ & $\begin{array}{l}\text { Ugwuono-Nike, } \\
\text { Enugu State }\end{array}$ & 2009 \\
\hline 43. Gregory University & Uturu & 2012 \\
\hline 44. Paul University & $\begin{array}{l}\text { Awka, Anambra } \\
\text { State }\end{array}$ & 2009 \\
\hline 45. Rhema University & $\begin{array}{l}\text { Obeama Asa, } \\
\text { Rivers State }\end{array}$ & 2009 \\
\hline 46. Tansian University & $\begin{array}{l}\text { Umunya, Anambra } \\
\text { State }\end{array}$ & 2007 \\
\hline $\begin{array}{l}\text { 47. Wesley University of } \\
\text { Science and Technology }\end{array}$ & Ondo, Ondo State & 2007 \\
\hline 48. Crescent University & $\begin{array}{l}\text { Abeokuta, Ogun } \\
\text { State }\end{array}$ & 2005 \\
\hline 49. Varitas University & Abuja & 2007 \\
\hline 50. Al-Qalam university & Katsina & 2005 \\
\hline 51. Augustine University & Ilara, Lagos & 2015 \\
\hline 52. Chrisland University & $\begin{array}{l}\text { Owode, Ogun } \\
\text { State }\end{array}$ & 2015 \\
\hline 53. Christopher University & Mowe, Ogun State & 2015 \\
\hline 54. Hallmark University & $\begin{array}{l}\text { Ijebu-Itele, Ogun } \\
\text { State }\end{array}$ & 2015 \\
\hline 55. Kings University & $\begin{array}{l}\text { Ode-Omu, Osun } \\
\text { State }\end{array}$ & 2015 \\
\hline 56. Michael and Cecilia Ibru & Owhrode, Delta & 2015 \\
\hline
\end{tabular}




\begin{tabular}{|cl|c|c|}
\hline University & State & \\
\hline 57. & Mountain Top University & Ogun State & 2015 \\
\hline 58. & Ritman University & $\begin{array}{c}\text { Ikot Ekpene, Akwa } \\
\text { Ibom }\end{array}$ & 2015 \\
\hline 59. & Summit University & Offa, Kwara State & 2015 \\
\hline 60. & Edwin Clark University & $\begin{array}{l}\text { Kiagbodo, Delta } \\
\text { State }\end{array}$ & 2015 \\
\hline 61. & Hezekiah University & Umudi, Imo State & 2015 \\
\hline 62. & CrownHill University & $\begin{array}{c}\text { Baallah, Ilorin, } \\
\text { Kwara }\end{array}$ & 2016 \\
\hline
\end{tabular}

\section{Nigeria}

Impacts of Economic Recession on Managing private universities in

The emergence of private universities in Nigeria has been explained in terms of several factors. These include: the public failure theory, the demand absorption theory and choice theory. Therefore, it is justifiable to say that private universities have contributed immensely to the development of higher education in the country. This is evident in terms of the boost in the number of students admitted into the universities, quality of infrastructures and facilities, assurance of the quality of programmes offered, quality of graduates produced, maintenance of stable academic calendar and effective check on the menace of secret cults among others (Fapounda, 2012).

Private universities have been placed at the center of public debate as a result of the present financial collapse and economic recession in the country. It is therefore very germane to say that the economic recession has serious impacts on the management of private universities at large. Thus, private universities are not immune to the hard times in the country.

The first and immediate shorter-term impact of the economic recession has been at the institutional micro level. Lower students' enrolment on certain programmes- the most expensive programmes and those with lower job prospects have led the private universities' administrators to prepare for the worst by making plans to reduce staff at all levels and rationalise their portfolio of programmes. Also, this has made many private universities to impose severe cut on their provision by cutting academic programmes that are not competitive.

Also, the era of economic recession has made it difficult for many parents to pay their children school fees. It should be noted that these universities largely rely on the fees remitted by parents as well as the goodwill of other donours whose economic buoyancy has been seriously affected by the downward trend globally. Corroborating this, the Vice-Chancellor of Redeemer's University, Prof. Adeyewa 
was reported to have said that in many private universities in Nigeria, parents have been unable to pay fees as due and there have been numerous plans to allow students to defer payment while some evel ask institutions to allow their wards to sit for examinations and pay the fees later (Punch Newspaper, July26, 2016). Also, the Vice-Chancellor of Al-Hikmah University, Prof. Mohammed Ibrahim lamented that some students could not sit for the last semester examinations following the non-payment of their tuition (Punch Newspapr, July 26, 2016).

More so, the economic recession has seriously affected the provision of needed materials, equipment and conducive environment for enhanced pedagogical activities in many private universities in the country. The running costs of these universities have risen drastically due to increase in the cost of diesel, fuels and other labouratory and technical equipment. The high cost of materials perhaps as a result of crashing of Naira has made the procurement of equipment impossible. Thus, these are impeding factors to the provision of conducive environment for both students and staff.

Furthermore, the present economic recession has seriously impacted on the recruitment process in many private universities in the country. Many private universities have put on hold the recruitment of additional staff in order to ensure that the salaries of the existing ones are paid. Some cannot even afford to recruit competent and academically inclined personnel and therefore place some staff on contract, adjunctship, associateship or part-time basis. This undoubtedly negatively affects the instructional delivery and subsequently the products of the system.

\section{Survival Strategies for Managing Private Universities in Nigeria during the era of Economic Recession}

It is very germane to emphasise the fact that the emergence of private universities in the Nigerian educational system is a welcome development that must not only be encouraged but sustained. In spite of the challenges and vicissitudes witnessed by these universities during the era of economic recession, certain strategies need to be put forward by the private universities so as to favourably compete, survive and exist during this era of economic malady or imbroglio. Some of these survival strategies are:

Introduction of market-driven curricular/ programmes- Private universities should introduce market-driven programmes in form of entrepreneurship programme to all students, irrespective of their chosen field of study. This programme should involve theory, practical and local internship in 
Entrepreneurship Development Studies within the university. It does not only help the private universities to make their graduate to be self-reliant but also enables the universities to sell the proceeds from such programmes, thereby serving as another source of revenue generation. This programme may include but not limited to the following:

1.Fish pond including fish mills

2.Snail farm unit

3. Grasscutter rearing unit

4.Soap making, including disinfectant and air freshners

5.Bead making unit

6.Hat-making unit

7.Paint making unit

8.Fruits and juice including water production unit

9.Tie and dye (Textile) unit

10.Printing and publishing unit

11.Production of bottled water and ICT Solution software

Old boys/ Alumni Associations- The relevance of alumni associations in the provision of financial supports for the private universities becomes very important in this era of economic recession. The alumni association from time to time can donate funds and other teaching and learning equipment to universities.

Other strategies include: forming of Stakeholders forum of Parents and Teachers Association within the university and procurement of external aids from outside the country. It is also important than private universities mount some other programmes that are productive and capable of generating more funds to the universities. This may include: floating of Sandwich or Part-Time Programmes for on-the-job workers who are yearning for university Degree and Top-Up/HND Conversion programme for the graduates of Polytechnics. This is considered lucrative as more polytechnic graduates are likely to enroll due to discrimination between university and polytechnic graduates.

\section{Conclusion and Recommendations}

This paper has vividly discussed the impacts of economic recession on the management of private universities in Nigeria and suggested strategies to be adopted by the private universities. It is there conclusive to say that economic recession has impacted several sectors of Nigerian economy, with education having its shares. Thus, managing private universities in this era of economic doldrums is 
a difficult task. It is therefore recommended that the government should endeavour to enact policy that will establish the allocation of funds to private universities in the country. This will enable the private universities to supplement such funds with the little they are able to realize at the individual institutional level. When government enacts the law for allocation of funds to private universities in the country, it will better improve the government's control and influence on the universities.

\section{Disclosure statement}

No potential conflict of interest was reported by the author.

\section{Contact Information}

E-mail: murainamonsuru@gmail.com 


\section{References and notes:}

Abrahamson, Mark. 2004. Global Cities. New York: Oxford University Press.

Chin-keong, Ng. 1992. "The Cultural Horizon of South China's Emigrants in the nineteenth Century: Change and Persistence." Pp. <put page numbers here $>$ in Asian Traditions and Modernization: Perspectives from Singapore, edited by Young Mun Cheong, Center for Advance Studies, NUS.

Chong, Alan, 2007. "Singapore's Political Economy, 1997-2007: Strategizing Economic Assurance for Globalization." Asian Survey 47(6):

Chong, Terence. 2011.The Theatre and the State in Singapore: Orthodoxy and Resistance. London: Routledge.

Clammer, John. 1998. Race and State in Independent Singapore 1965-1990: The Cultural Politics of Pluralism in a Multiethnic Society. Vermont: Ashgate Publishing Company.

Dales, Johan 1999. Urban Planning in Singapore, the Transformation of a City, London: Oxford University Press.

Douglass, Mike. 2009. "Globopolis or Cosmopolis? - Alternative Futures of City Life in East Asia", Journal of Urban Humanities

Gertler, Meric S. 1997. "Between the Global and the local, the spatial limits to productivity capital." Pp. <put page numbers here> in Spaces of Globalization: reasserting the power of the local, edited by Kevin R Cox. New York: The Guilford Press

Goh, Daniel P. S. 2009. Race and Multiculturalism in Malaysia and Singapore, London: Routledge

Hui, OngJie, at all. 1997. Understanding Singapore Society. Singapore: Times Academic Press

Kearney, A. T. 2010. "Global Cities Index Ranks New York, London, Tokyo and Paris as top Global Cities," The Chicago Council on Global Affairs, and Foreign Policy, October 4

King, Anthony. 2007. Spaces of Global Cultures, Architecture Urbanism Identity. Routledge: London.

Koh, Ai Tee, Lim K Lian, Weng Tat Hui,,BhanojiRao, and ChngMengKng. 2002. Singapore Economy in the 21th century. Singapore:McGraw Hill.

Kong, Lily. 2007. Cultural icons and urban development in Asia: Economic imperative, national identity. Political Geography 26

McCharty, Stephen. 2006. The Political Theory of Tyranny in Singapore and Burma: Aristotle and Rhetoric benevolent despotism. London: Routledge.

Lim, William S.W. 2005. Asian Ethical Urbanism: A Radical Postmodern Perspective. Singapore: World Scientific Publishing Copie.

Ling, OoiGiok. 2004. Future of Space: Planning, Space, and the City. Singapore: Marshall Cavendish.

Olds, Kris and Henry Wai-Chung Yeung. 2004. "Pathways to Global City Formation: A View from the Developmental City-State of Singapore", Review of International Political Economy, 11/3

Poon, Angelia. 2009. "Pick and mix for a global city:race and cosmopolitan in Singapore." Pp. <insert page numbers here> in Race and Multiculturalism in Malaysia and Singapore, edited by Daniel PS Goh, London: Routledge 
Sassen,

Saskia.

2000.

The

Global

City:

StrategicSite/NewFrontier,journals.ku.edu/amerstud/2000

Sassen, Saskia. 2001. The Global City, New York, London, Tokyo (second edition). New Jersey: Princeton University Press.

Sassen, Saskia. 2002. Global Networks, Linked Cities. New York, Routledge

Taylor, Peter J., D.R. F. Walker, and J. V. Beaverstock. 2002. "Firms, and their Global Service Networks.” Pp. <insert page numbers here>, in Global Networks, Linked Cities, edited by SaskiaSassen. New York, Routledge

Schmidt, Vivien A. 1999. "Convergent pressures, divergent responses, France, Great Britain, and Germany between globalization and Europeanization." Pp. 173<insert other page number here>, in States and Sovereignty in the Global Economy, edited by, in David A Smith <and list the other editors as well; et al. doesn't work here>. London: Routledge.

Vasil, Raj. 1995. Asianizing Singapore. Heinemann Asia: Singapore.

Vale, Lawrence J. 1992. Architecture, Power, and National Identity. New York: Routledge.

Velayutham, Selvaraj. 2007. Responding to Globalization: Nation, Culture, and Identity in Singapore. ISEAS: Singapore.

Yah, Lim Chong. 2009. "Transformation in Singapore Economy: course and cases." Pp. <insert page numbers here>, in Singapore and Asia in a Globalized World, Contemporary Economic Issues and Practice, edited by Chia W Mun, and SngHui Ying. Singapore: World Scientific.

Yun, Hing Ai. 2001. "Reconstituting the Middle Classes: Teachers, the Evaluative State and the Market in Singapore." Pp. <insert page numbers here>, in Southeast Asian Middle Classes, Prospects for Social Change and Democratisation, edited by in Abdul $\mathrm{R}$ Ambong. Kuala Lumpur: UniversitiKebangsaan Malaysia

Washington Post, 2001, Newsweek Interactive, LLC, Measuring Globalization, Foreign Policy, No. 122 (Jan. - Feb), p. 57 